\title{
Conto de fadas
}

\author{
Fairy tale
}

\section{Azzurra Rinaldi}

Ele até era lindo. Quer dizer, nunca tive interesse por ele, mas, como se confessou, comecei a olhar para ele em maneira diferente do que o costume: magro, aliás, demasiado magro; olhos grandes e escuros; cabelo curto, mãos grandes típicas dos músicos.

"Nada a fazer não, não pode ser! Ainda que eu quisesse não podemos e sabes bem que não podemos!"

"Pois, eu sei! Desculpa o desabafo. Eram tantos anos que eu queria..."

$\mathrm{O}$ ar frágil dele, a fragilidade de uma criança que viveu o divórcio dos pais de maneira péssima, como eu, de resto. Acabamos por morar juntos como "irmãos": ele, filho da mulher do meu pai, e eu, filha do meu pai que, sendo médico, tratava os meus problemas de saúde. Morávamos juntos, brincávamos, até que ele se foi embora para Florença e começar cursos na faculdade que nunca acabou. Deixamos de falar. Afastamo-nos depois daquele dia de Natal em que me convidou para beber um café no bar ao pé da casa do meu pai e da sua mãe.

"Imagina a cara da tua mãe se acontecesse algo entre nós!" disse eu mexendo a colher no café sem açúcar, pois aquela cena parecia-me demasiado doce para ser estragada com ainda mais doçura.

"Minha mãe... que se lixe!"

A harpia, a bruxa, a vaca, eu chamava-lhe assim. Comigo sempre foi má como pretendem os estereótipos das madrastas dos contos de fadas. Porém na vida real não há fadas nem príncipes encantados; ele de certeza que não o era! O filho da bruxa... deuses me livrem!

"Só por causa dela?"

"Sei lá...”"

A atmosfera estava tensa que dava para cortar à faca, mas ainda pior foi quando ele pegou na minha mão e levou-a ao seu rosto. Nada disso em si mesmo era mau senão fosse que naquele instante entrou no café a senhora bruxa. Eu sabia que ela sabia que estava acontecendo alguma coisa estranha entre mim e o filho dela. Ah, pois é, bruxa! Feia, com o nariz grande e o corpo magro, demasiado magro. O que é que o meu pai viu nela permanece um mistério, só encantamento podia ser. Até o nome dela era feio: Castrite, ninguém merece!

Olhou para nós tão cruelmente que acabei por sentir mil agulhas penetrar no meu corpo.

Eu, a burra, a gorda, a filha da minha mãe, seduzi o filho, o único macho dela, o que pode perpetuar o apelido nobre, a condessa. Perpetuar a linhagem, nem que estivéssemos na Idade Média! Ela obrigou o filho a pôr o apelido dela, coisa não comum em Itália, para que a descendência se pudesse lembrar da antiga nobreza o casado dos Merdinozi. E ele silencioso não podia dizer que não e o pôs sem dizer uma palavra, desde que era Daniele Puceni acabou por se tornar Daniele Puceni Merdinozi, para a felicidade da mãe e do resto da família toda.

“Então estão cá?" Disse aproximando-se, no entanto que o filho já tinha deixado cair a minha mão na mesa: "Olha que príncipe corajoso" pensei "como é que acabei por fazer parte de tudo isso?"

"Então, filho, o que é que está a fazer a tua namorada em Florença? Já encontrou trabalho?” perguntava a ele, olhando para mim.

Em toda a sua bruxaria não tinha entendido que a vítima ali era eu. Ele tentava seduzir-me, não o contrário!

Também o príncipe olhou para mim antes de responder, estava à espera da minha ajuda ou de uma reação minha ao facto de ele ter a namorada, mas nada disso the chegou.

"Mãe, a história acabou."

"Não me disseste nada, porquê?"

"Porque nunca te conto nada, mãe!" 
Um relâmpago caiu: o meu susto em ouvir aquela frase, o brilho dos olhos do príncipe e o olhar de ódio da bruxa. Eu fiquei no meio dos dois parada, embora, naquele instante, só me tivesse apetecido levantar-me da cadeira e beijar o príncipe por ter dito aquela frase tão heroica que se revelou uma facada nas costas da bruxa. Finalmente o príncipe fez algo de verdadeiramente heroico e eu não me podia mexer! Agora, que disse aquela frase que provocou o espanto não me conseguia levantar para agradecer da coragem que teve: estava bloqueada, com as pernas moles, sem força, paralisada.

Olhei para os dois, sem saber o que estava a acontecer, assustada, com medo de que me poderia acontecer algo de verdadeiramente mau. Depois da sensação das agulhas na pele, tinha as pernas desligadas do cérebro, queria fugir, ir longe - aliás sempre quis fugir da minha vida - mas agora a sensação de medo e de horror me tinha preso não apenas psicologicamente como era no passado, mas também fisicamente: imobilizada com a pele que parecia sangrar de tanto ódio que a bruxa sempre teve por mim.

"Mãe, deixa lá estar!"

Tinha os pulsos presos na mesa, a minha boca colada: queria gritar e não conseguia. O que era aquela bruxaria toda? Bruxaria de verdade! Não era sonho, nem pesadelo, nem visão. Tudo o que me estava a acontecer era real, dramaticamente verdadeiro.

O príncipe olhava para mim com o ar de desespero sem saber o que podia fazer:

"Mãe, para com isso!"

Porque ele acha normal esta situação? Acorda, acorda, acorda, acorda! Não, não me conseguia libertar. Entretanto as outras pessoas que estavam no local desfizeram-se em fumo e, no bar, só ficámos a bruxa, o príncipe e eu - a donzela que deveria ser salva por um herói que desafortunadamente não era o que eu tinha à minha frente. Talvez o açúcar tinha dado jeito agora nesta situação já não muito doce e que começava a cheirar a enxofre.

"Mãe!"

"Ela" disse a bruxa a ele "pequena mosca que nunca suportei!" e voltou-se logo para mim com olhos de carvão "Só te tive na minha casa por causa do teu pai! $\mathrm{Tu}$, sempre com aquele arzito de superioridade! Tu não podes interferir com a minha família! Se só não fosses filha do teu pai já tinhas morrido, pequena bastarda filha da mãe. Já não chega a tua maldade contra a mim: tu, que me chamavas de bruxa. Tu nunca mereces respeito e podes até ganhar o Nobel, sempre serás uma pobrezita gorda, feia e idiota."

Vi os olhos dela transformarem-se em fogo. Agora, mais do que bruxa ela era demónio: a sua cara vermelha deixava transparecer a forma do esqueleto, o cabelo uma vez loiro - fez-se preto, as suas unhas tornaram-se chamas cor de laranja e vermelhas que podiam cegar se olhadas direitamente e a sua voz, que nunca teve nada de melódico, parecia sair de uma cratera de um vulcão.

"Morrerás, nunca te suportei e agora ainda menos depois de teres seduzido o meu filho!"

Eu, imóvel, com aquela monstruosidade à minha frente só queria morrer. Preferia que a minha vida acabasse do que suportar aquelas torturas. O meu coração palpitava, estava tremendamente lúcida, mas não me podia mexer: o meu corpo não me obedecia. Só estava a aguardar a morte, esperando que fosse rápida, embora conhecendo a mulher nunca poderia ter direito ao último desejo, nem sequer a um decesso rápido; pois ela gostava demais de aquela situação: o meu sofrimento dava-lhe satisfação e era patente o seu prazer em ver-me ali cheia de sangue, paralisada e sem uma boca para chamar socorro.

"Mãe!"

"Agora verás o que é estar contra a nossa nobre família!"

Só tive o tempo de olhar para o teto carbonizado do café, sempre se ainda estivéssemos no café, e sentir na minha pele tantas lâminas cair-me do alto. Se só pudesse perder os sentidos! Mas não aqueles estavam bem ativos. Sofrer o que já tinha sofrido por dento não bastava para ela, pois o olhar o meu corpo lacerado deveria dar-lhe mais satisfação do que tentar fazer de mim uma insegura deprimida.

"Mãe! Para com isso, já!"

Nunca ouvi voz mais espantosa até que a da bruxa me parecia suave. Surgiu à minha frente um homem magro, demasiado magro, com as mãos grandes como as dos músicos. Ele, o príncipe acordou e finalmente tomou a minha defesa.

"Sempre foste mau comigo, filho, mas agora que estou com as mãos na massa pensarei em ti também! Sempre a defender o teu pai! Eu engravidei, tinha dezoito anos, achas que realmente te queria? Tive-te, amei-te muito, mas sempre me achaste louca. Passei sobre este teu 
feitio, pois compreendia o teu sofrimento, mas namorar com ela, isto não! Tomar as suas defesas contra mim? Pagarás, filho, pagarás também!"

Eu vigilante olhava para os dois coberta de sangue, queria acabar com a minha vida e eles decidem de ter este tipo de conversa! Estava paralisada numa cadeira de um bar, em um qualquer círculo infernal e eles querem desabafar agora. Quero morrer já! Os assuntos deles não me interessavam, nunca tive interesse nas relações entre eles. Sempre me quis manter fria, destacada de tudo o que acontecia lá em casa, até chegar a um ponto de não sentir nenhuma dor dentro de mim. Nada podia me tocar nos anos em que lá vivia, mas agora, que o sofrimento era físico e o medo tão grande só queria deixar que a minha vida se fosse embora de mim para encontrar um lugar melhor no Outro Mundo das fadas.

"Mãe, para. Voltamos à vida normal. O que é que vai pensar o teu marido quando perceber que a filha desapareceu?"

"Nada, como sempre, nunca teve coragem comigo e mesmo nesta situação não dirá nada. Aliás, sempre me defendeu."

Confirmo. Maldita bruxa, maldito diabo! O meu pai nunca me defendeu e sempre te justificava. Tinhas a capacidade de o virar como uma meia: "amorinho" e "Nicolzinho" deviam ser as palavras mágicas para o encantar, pois o meu pai sempre te deu razão em tudo. Lembro da "mesa inquisitorial" quando chegava da escola e tinha feito uma asneira qualquer, ou aos domingos de manhã: ele fazia as perguntas e tu lá a ouvir e olhar para mim como para tomar notas das minhas culpas.

Afinal das contas, eu era a má, pois o meu comportamento era influenciado pela "louca" da minha mãe. Oito anos passados na vossa casa, oito e sempre a submetida a palavras de escárnio: "nenhum de nós quer falar contigo", "claro que tiveste a nota mais alta, a tua escola é mais fácill", "nem os teus professores te suportam", "és uma burra", "não viste que barriga que tens"... oito anos... Até ao ponto de tu, condessa bruxa, me quereres fora de casa, mas não, não fui: vingança. Foi por vingança que fiquei outros dois anos, ficar à tua frente durante almoços e jantares, ficar em casa para que tu pudesses sentir a minha presença. Foram anos duros também para mim, mas a satisfação de te olhar e te sorrir como para dizer "estou cá ainda", mereciam cada hora de sofrimento. Agora, parece que obteve a minha punição: queimar nas chamas do inferno que tu criaste. Se só tivesse posto o açúcar no café.

Olhei, cansada, para o príncipe cuja coragem voltara a ser fragilidade e parecia ainda mais magro do que era: não podia vencer o poder espantoso do demónio que estava ali e, evidentemente, nem queria arriscar demasiado a sua vida para me salvar. Ele olhou para mim, queimada e cheia de sangue, imóvel sentada numa cadeira de um café desaparecido.

Lembrei que nos anos passados em casa daquela bruxa aprendi a não sentir as chagas que tinha dentro, portanto, naquele momento, aprendi a deixar de sentir a dor física. A minha preocupação agora não era a de morrer, mas era a de continuar a olhar para o demónio nos olhos, como dantes fazia, e vingar-me com um simples: "aqui estou" gritado através do olhar.

Foi a minha coragem que a destruiu, a minha coragem transparecia através dos meus olhos, nunca disse uma palavra, a minha guerra com ela era combatida através de olhares e apesar das feridas sangrantes, do suor e do cheiro a carvão, eu estava a lutar com os meus olhos, a única parte que ainda podia mexer. Não me salvei, pois não podia, mas resisti até ao fim, até ao momento em que tudo tornou normal: o café, as pessoas, o dia de Natal. Só eu não me encontrava sentada na mesa do bar, porque estava livre do pesadelo da minha vida. Nos contos de fadas são os príncipes que salvam as princesas das bruxas, mas as fadas na vida real não existem e os príncipes encantados também não, porém há bruxas por todo o lado e para cada uma delas há uma ou mais princesas que as combatem como podem: eu escrevo, tornei-a demónio e coloquei-a nos infernos.

\footnotetext{
Recebido: $15 / 12 / 16$

Aprovado: 08/03/17

Contato: rinaldi30@hotmail.com
} 